\title{
The Effect of Various Wavelengths of LED Light on the Physiological and Morphological Parameters of Comfrey (Symphytum officinale L.)
}

\author{
Nuri Çağlayan ${ }^{1, a, *}$, Esra Uçar Sözmen²,b, Can Ertekin ${ }^{3, c}$ \\ ${ }^{1}$ Department of Mechatronics Engineering, Faculty of Engineering, Akdeniz University, 07058 Antalya, Turkey \\ ${ }^{2}$ Department of Medicinal and Aromatic Plants, Sivas Vocational School, Cumhuriyet University, 58140 Sivas, Turkey \\ ${ }^{3}$ Department of Agricultural Machinery \& Technology Engineering, Faculty of Agriculture, Akdeniz University, 07058 Antalya, Turkey \\ *Corresponding author

\begin{tabular}{|c|c|}
\hline A R T I C L E I N F O & A B S T R A C T \\
\hline $\begin{array}{l}\text { Received : 03/12/2019 } \\
\text { Accepted : 12/03/2020 }\end{array}$ & $\begin{array}{l}\text { The aim of this study was to examine the effect of five different wavelengths of light on the comfrey } \\
\text { plant (Symphytum officinale) (family Boraginaceae). The light source and wavelengths used in the } \\
\text { study were UV-A (390-410 nm), blue (465-485 nm), red }(620-630 \mathrm{~nm} \text { ) and cool white }(\mathrm{CW}) \text { daylight } \\
(400-700 \mathrm{~nm}, 6500 \mathrm{~K}) \text {, LED (Light Emitting Diode). In the study, each of the } 5 \text { different light } \\
\text { applications was applied for } 45 \text { days (T1: } 100 \% \text { blue; T2: } 100 \% \text { red; T3: } 60 \% \text { blue }+35 \% \text { red }+5 \% \\
\text { UV-A; T4: } 100 \% \mathrm{CW} \text { daylight; T5: } 80 \% \mathrm{CW}+20 \% \mathrm{red}) \text {. The experiments were carried out under } \\
\text { conditions of } 22^{\circ} \mathrm{C} \text { temperature, } 60 \% \text { humidity, } 16 / 8 \text { hours light/dark and } 180 \mu \mathrm{mol}^{-2} \cdot \mathrm{s}^{-1} \\
\text { Photosynthetically Active Radiation (PAR). After each application, measurements were taken of } \\
\text { number of leaves, number of roots, height of plant, amount of chlorophyll in leaves, leaf colour and } \\
\text { brightness. According to data obtained, the different wavelengths of the coloured light applied in the } \\
\text { growing environment created a change in colour and brightness of the leaves, height of the plant, } \\
\text { length of the roots, and number of leaves and roots. }\end{array}$ \\
\hline
\end{tabular} \\ LAB
}

LED

Light \section{(1)}


2007). If red and blue light is given together, it promotes blooming and seed production in plants. If amount of light in greenhouse plant production is not sufficient for plant growth, synthetic light sources can provide lacking photosynthetic active radiation (PAR) energy. LED lamps that can emit a specific wavelength of light, are preferred for artificial illuminations (Caglayan and Ertekin, 2011).

Recent developments in artificial light source technology have opened new horizons for LED structures that are both sustainable and highly productive. Results of economic analyses comparing LED and traditional light sources have shown that LED could reduce the long-term costs of plant production because of the high energy effect, low maintenance cost and long life. Studies have been conducted, which have examined the responses given by different plant species to different wavelengths to be able to understand whether LED could really be an alternative to traditional light sources. However, there is a need for more detailed research to understand the effect on the plant physiology of different LED wavelengths (Caglayan and Ertekin, 2016).

In this research, effect of various wavelengths [UV-A (390-410 nm), blue (465-485 nm), red (620-630 nm) and cool white $(\mathrm{CW})$ daylight (400-700 nm; $6500 \mathrm{~K})$, LED (Light Emitting Diode)] of LED light on growth parameters $\left(L^{*}, a^{*}, b^{*}\right.$ values, amount of chlorophyll, leaf number, root number, plant length, root length) of the comfrey plant was investigated. The aim of the study was to find alternative light sources to increase plant yield in growth environments where natural and traditional light sources are insufficient.

\section{Material and Method}

\section{Establishment of the LED Lighting System and the Plant Experiment}

Shoots were grown from rhizomes of comfrey in pots (two weeks). When the plants were $10 \mathrm{~cm}$ in height, they were transferred to the experiment environment (plant growth cabinet) and the growth procedures were applied. The plant growth cabinet (Nuve, TK252) has a capacity of 252 litres and its climate can be controlled. The experiments were conducted as a randomized complete design method with three replications (five plants for each application). The light source used in the study was Light Emitting Diode (LED) at wavelengths of UVA (390-410 $\mathrm{nm})$, blue (465-485 $\mathrm{nm})$, red (620-630 nm) and CW daylight (400-700 nm; $6500 \mathrm{~K})$. Each of the five different light applications was applied for 45 days $\left(\mathrm{T}_{1}: 100 \%\right.$ blue; $\mathrm{T}_{2}: 100 \%$ red; $\mathrm{T}_{3}: 60 \%$ blue $+35 \%$ red $+5 \%$ UV-A; $\mathrm{T}_{4}:$ $100 \% \mathrm{CW}$ daylight; $\left.\mathrm{T}_{5}: 80 \% \mathrm{CW}+20 \% \mathrm{red}\right)$. The study was carried out in conditions of $22^{\circ} \mathrm{C}$ temperature, $60 \%$ humidity, $16 / 8$ hours light/dark and $180 \mu \mathrm{mol} . \mathrm{m}^{-2} . \mathrm{s}^{-1}$ Photosynthetically Active Radiation (PAR). The light sources used in the study were $\mathrm{CW}$ daylight, blue, red (CREE XLamp XP-C) and ultraviolet (UVA) (EDISON Opto- Edixeon S) LEDs (Figures 1a, b, c, d). A LED group was formed from each colour of the same wavelength LEDs connected in parallel or serially in a pattern. The organization of the LED groups was shown in Figure 1 and the technical properties of the LEDs were shown in Table 1.
To select the wavelength for each LED group and to adjust the amount of light, separate Pulse Width Modulation (PWM), 186 W, $30 \mathrm{Vdc}, 6.2$ A LED driver (Mean Well Inc, 2019) were used. The performance of the drivers varied between $70 \%$ and $95 \%$ depending on the output strengths and quality of the electronic circuit design. At the beginning of each experiment, the PAR value was adjusted by changing the PWM square wave signal from the control entry of the driver providing the energy to each LED group as shown in Figure 2. The mean sign of the square of the wave frequency $f_{(t)}$, the lowest general value $y_{\min }$, the highest general value $y_{\max }$ and the duty cycle D was: (Equation 1)

When $f_{(t)}$ square wave was

$$
\bar{y}=\frac{1}{T} \int_{0}^{T} f(t) \mathrm{dt}
$$

$f_{(t)}$, values of $D . T<t<T$ can be obtained for $y_{\min }$ and $0<t<D . T$ for $y_{\max }$. The following formulae was obtained (Equation 2, 3 and 4);

$$
\begin{aligned}
& \bar{y}=\frac{1}{T}\left(\int_{0}^{\mathrm{DT}} y_{\max } \mathrm{dt}+\int_{\mathrm{DT}}^{T} y_{\min } \mathrm{dt}\right) \\
& \bar{y}=\frac{D \cdot T \cdot y_{\max } d t+T(1-D) y_{\min }}{D \cdot y_{\max }+(1-D) y_{\min }} \\
& \bar{y}=D \cdot y_{\text {max }}+(1-D) y_{\text {min }}
\end{aligned}
$$

The equations were used as $y_{\min }=0$ and $\overline{\mathrm{y}}=\mathrm{D} \cdot \mathrm{y}_{\max }$. The mean value obtained depends on the duty cycle (Huang et al., 2011).

The ability to adjust the severity levels of LED light between 0 and $100 \%$ and in very small gradations, is provided with control of the pulse widths produced with PWM (Figure 3). This procedure can be applied by the control card sending numerical signs to the driver in a sensitive manner and without vibration in the light. The Arduino Uno control card was used for PWM control. The light control of the LED groups is shown in block form in Figure 4.

\section{Quality Analyses}

The amounts of chlorophyll (from the leaf with a chlorophyll meter (SPAD 502) measured three times and average values were calculated), L, a, b values, stem and root lengths, the number of leaves and roots of the plant were measured (Zhu et al., 2012). In determining colour changes in leaves, leaf samples were measured using a chroma meter (Minolta CR-200) as CIE L, $a, b$. L value. When the value of $\mathrm{L}$ is 0 , this indicates black colour, with no reverberation and when $\mathrm{L}=100$, this indicates white colour with full reverberation (Figure 5). Positive "a", negative "a", positive "b" and negative "b" values represent red, green, yellow, and blue, respectively. At the point of zero-cut $(a=0$ and $b=0)$, it becomes colourless or grey (Figure 6). Chroma $\left(\mathrm{C}^{*}\right)$ and hue angle $\left(\mathrm{h}^{*}\right)$ values were calculated using the equation 5 and 6 below (McGuire, 1992).

$$
\begin{aligned}
& C^{*}=\sqrt{ }\left(a^{*}\right)^{2}+\left(b^{*}\right)^{2} \\
& \left.h^{\circ}=\tan ^{-1}\left(a^{*} / b^{*}\right)\right]
\end{aligned}
$$


The angle formed by the $\mathrm{X}$ axis crossing the intersection point of the hue angle, $a^{*}$ and $b^{*}$ values (McGuire, 1992). A hue angle of $0^{\circ}, 90^{\circ}, 180^{\circ}$ and $270^{\circ}$ represent red, yellow, green, and blue, respectively. The chroma value represents the vitality-opacity of the leaves with a low chroma value in dull colours and a high chroma value in bright colours (Anonymous, 1996). After measurements of the amount of chlorophyll and colour, measurements were taken of the number of leaves and roots, the height of the plant and the length of the roots.

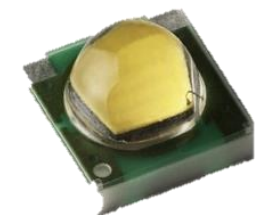

(a)

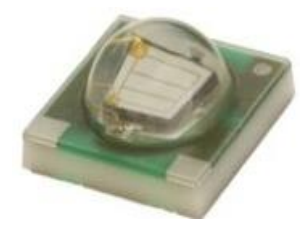

(c)

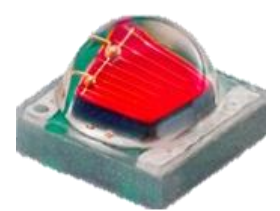

(b)

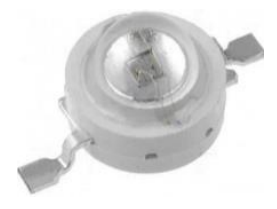

d)

\section{Statistical Analysis}

The experiment was conducted as a randomized complete design method with three replicates. The obtained data was analysed using analysis of variance and the Duncan grouping method was performed to determine whether there was a relationship between the different light applications. MSTAT-C software was used for analysis of the data (Freed, 1988).

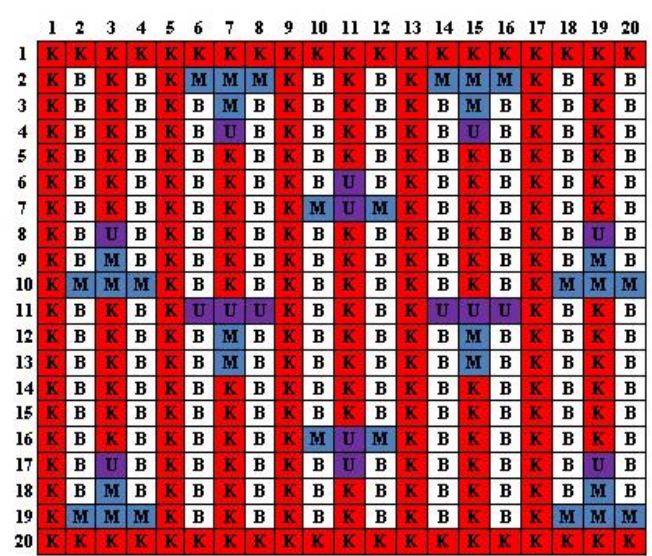

K: Red M: Blue B: Daylight U: UV-A

(e)

Figure 1. a) CW daylight, b) Blue, c) Red, d) UVA and e) LED placement

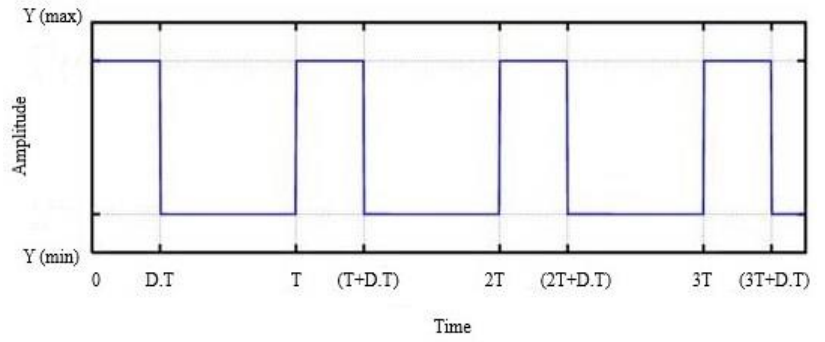

Figure 2. PWM wave ymin, ymax and D parameters

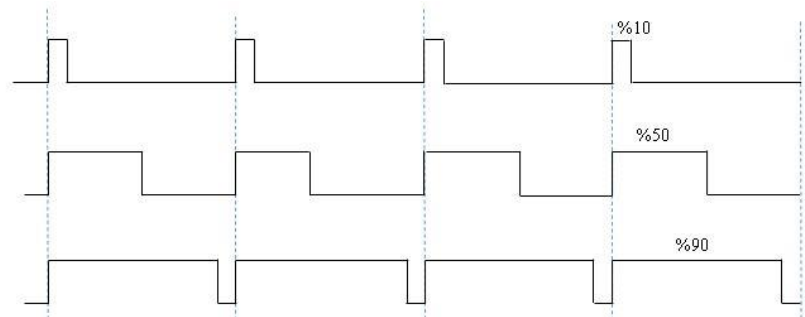

Figure 3. PWM ratios determining the light level

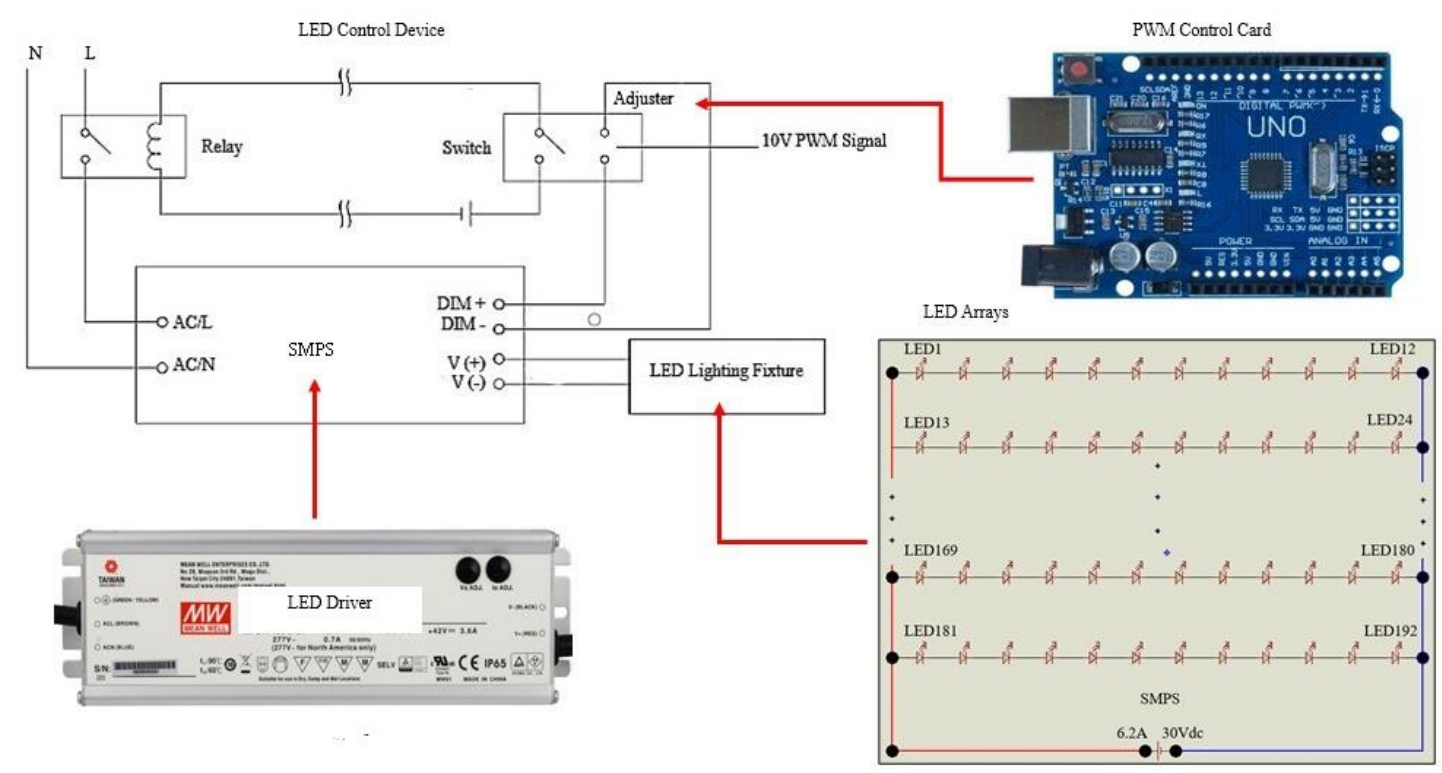

Figure 4. Block schematic form of the light level control 


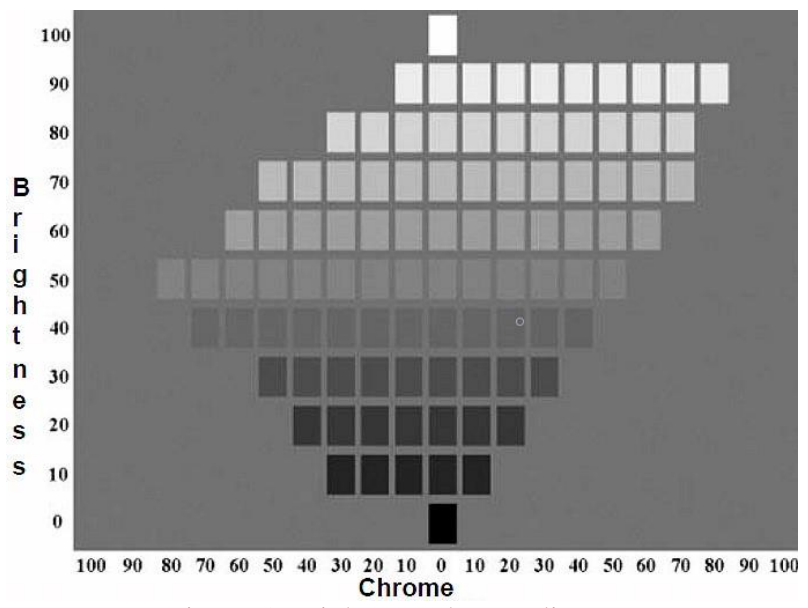

Figure 5. Brightness-chrome diagram

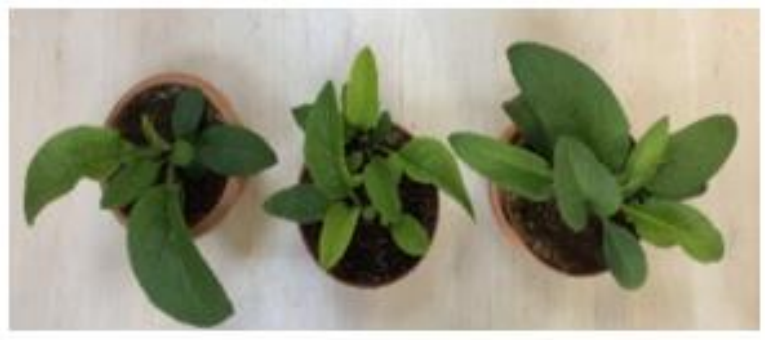

(a)

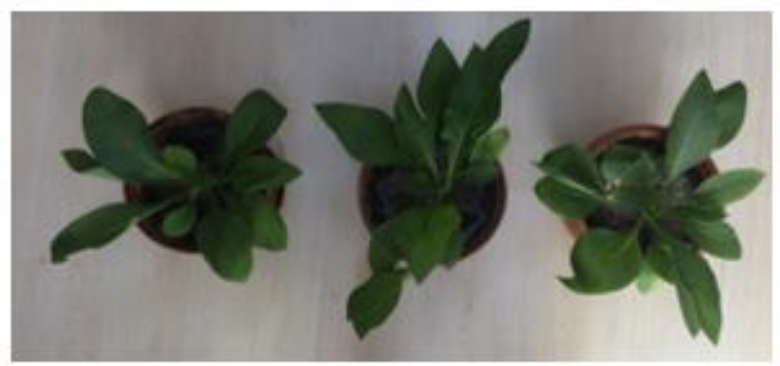

(c)

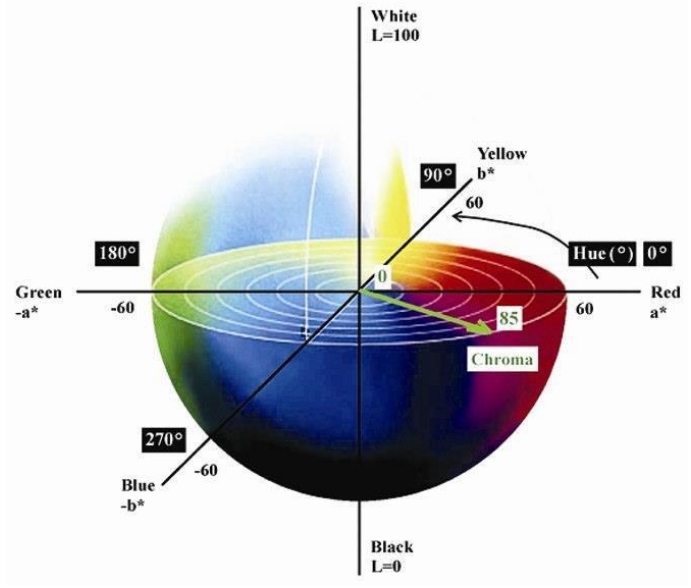

Figure 6. CIE $L * a * b *$ colour space diagram
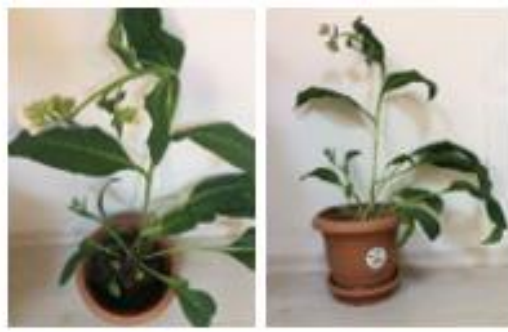

(b)

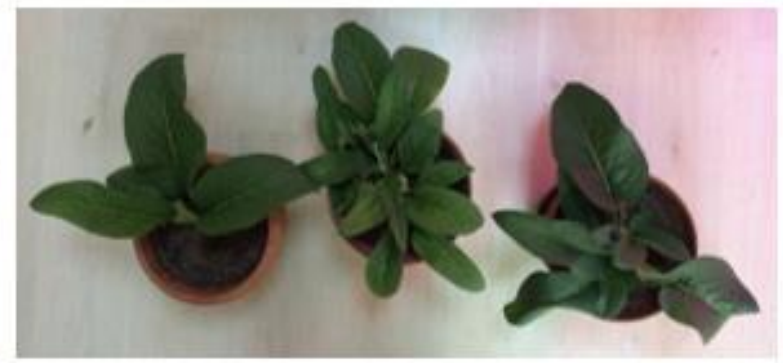

(d)

Figure 7. Appearance of the plants at the end of the experiment, a) CW, b) Red, c) Blue and d) Red + Blue + UVA

\section{Result and Discussion}

In this study, a LED lighting system has been designed and applied to provide the PAR energy necessary in plant growth cabinet applications. In LED lamp, the LED series giving cool white, red, blue and ultraviolet lights are efficient in increasing the photosynthesis rate. The Arduino Uno control card was used for selection of LED series and light level control.

Red and blue lights have the greatest impact on plant growth, because they are the major energy sources for photosynthetic $\mathrm{CO} 2$ assimilation in plants. Past studies examined the action spectra for photosynthesis of higher plants. It is well known that action spectra have action maxima in the $\mathrm{B}$ and $\mathrm{R}$ ranges. Combined $\mathrm{R}+\mathrm{B}$ LED lights were proven to be an effective lighting source for producing many plant species in controlled environments. The paper used the LED light source of adjustable parameter as crop growth light source, with red, blue LED combination collocation design, LED red light could inhibit photosynthetic product output from leaf to increase leaf starch accumulation; LED blue light regulated the physiological process of chlorophyll formation, chloroplast development, stomata opening, rhythm of photosynthetic and so on, meet the needs of crop growth photosynthesis for light conditions. Throughout the 45-day period of the experiment, 5 different wavelengths $\left(T_{1}, T_{2}\right.$, $\mathrm{T}_{3}, \mathrm{~T}_{4}, \mathrm{~T}_{5}$ ) were applied in the growing environment of the comfrey plants. After each application, measurements were taken of the number of leaves, the number of roots, root length, height of the plant, amount of chlorophyll in the leaves, leaf colour and brightness (Table 2). According to the data obtained, the different wavelengths of the coloured light applied in the growing environment created a change in the colour and brightness of the leaves (Figure 7). Growth, yield and quality of plants associated with both genetic and environmental factors. Light, plant nutrition elements, quality of water and temperature are necessary and important for plant growth (Yağcioğlu, 1996). 
While the closest hue angle values to green were determined in applications 1,4 and 5, the brightest leaf colour was determined in application 4. The highest amount of chlorophyll was determined in application 2 with $100 \%$ red light. Although the green colour of a leaf and the amount of chlorophyll was expected to be directly proportional, this was not the case in this study. When the green colour of the leaves was evaluated, statistical differences were determined between the applications, however numerically there was not much difference. When evaluated on the basis of the amount of chlorophyll, application 2 can be said to have been effective on the green colour of the leaves. There are indirect or direct effects of light intensity and light type time on plant growth together with photosynthesis ratio and dry matter production increasing (Matsuda et al., 2004; Spalding and Folta, 2005).
Chlorophyll molecules absorb blue (460-480 nm) and red $(650-700 \mathrm{~nm})$ radiations better and these wavelengths are more effective on plant growth (Yeh and Chung, 2009). Tripathi and Brown (1995) emphasized the effect of red LED light on chlorophyll synthesis. In a study carried out by Li et al. (2012), blue (440 and $476 \mathrm{~nm}$ ) and red LED were used together on Chinese cabbage and it was concluded that this combination caused a higher rate of chlorophyll. Ucar et al. (2016) obtained maximum chlorophyll amounts with $50 \%$ blue light $+50 \%$ red light in stevia plant. When the brightness of colour was evaluated as represented by the $\mathrm{L}$ value, the best value in respect of leaf brightness was determined in application 4 with $\mathrm{CW}$ daylight. The best values in respect of plant height, number of leaves and root length were determined in applications 2 and 3, and the highest root count was found in application 5.

Table 1. Technical properties of the LEDs used in the study

\begin{tabular}{l|cccc}
\multicolumn{1}{c}{ Technical property } & \multicolumn{3}{c}{ LED } \\
\cline { 2 - 5 } & CW & Red & Blue & UVA \\
\hline Colour heat $(\mathrm{K})$ & 6500 & - & - & - \\
wavelength $(\mathrm{nm})$ & $400-700$ & $620-630$ & $465-485$ & $390-410$ \\
Light flow $(\mathrm{lm}),(\mathrm{mW})$ & $100 \mathrm{~lm}$ & $45.7 \mathrm{~lm}$ & $23.5 \mathrm{~lm}$ & $528 \mathrm{~mW}$ \\
Colour conversion index $(\mathrm{CRI})$ & 70 & - & - & - \\
Operating current $(\mathrm{mA})$ & 350 & 350 & 350 & 700 \\
Operating force $(\mathrm{V})$ & $3.2-3.9$ & $2.2-2.5$ & $3.3-3.9$ & 3.4 \\
Power $(\mathrm{W})$ & 1 & 1 & 1 & 3 \\
Heat resistance $\left({ }^{\circ} \mathrm{C} \mathrm{W}^{-1}\right)$ & 12 & 10 & 12 & 15 \\
Angle of light radiation $\left({ }^{\circ}\right)$ & 115 & 125 & 125 & 120 \\
Package form & & Surface Mount Device (SMD) & \\
\hline
\end{tabular}

Table 2. The effect of lighting applications in wavelength on morphological and physiological properties of the comfrey plant

\begin{tabular}{c|cccccccc}
\hline Applications & $\mathrm{L}$ & Hue angle & Chroma value & K & PL & LN & RL & RN \\
\hline $\mathrm{T}_{1}$ & $42.07^{\mathrm{c}}$ & $156.7^{\mathrm{a}}$ & $24.13^{\mathrm{b}}$ & $21.37^{\mathrm{d}}$ & $36.33^{\mathrm{b}}$ & $11.00^{\mathrm{b}}$ & $27.67^{\mathrm{c}}$ & $3.3^{\mathrm{b}}$ \\
$\mathrm{T}_{2}$ & $38.70^{\mathrm{d}}$ & $152.7^{\mathrm{b}}$ & $14.73^{\mathrm{c}}$ & $53.63^{\mathrm{a}}$ & $33.00^{\mathrm{c}}$ & $15.33^{\mathrm{a}}$ & $35.33^{\mathrm{a}}$ & $3.0^{\mathrm{b}}$ \\
$\mathrm{T}_{3}$ & $37.63^{\mathrm{d}}$ & $149.0^{\mathrm{c}}$ & $15.77^{\mathrm{c}}$ & $31.97^{\mathrm{b}}$ & $83.67^{\mathrm{a}}$ & $14.00^{\mathrm{a}}$ & $34.0 \mathrm{a}^{\mathrm{b}}$ & $3.3^{\mathrm{b}}$ \\
$\mathrm{T}_{4}$ & $48.90^{\mathrm{a}}$ & $157.7^{\mathrm{a}}$ & $32.50^{\mathrm{a}}$ & $10.70^{\mathrm{e}}$ & $35.33 \mathrm{~b}^{\mathrm{c}}$ & $11.67^{\mathrm{b}}$ & $15.0^{\mathrm{d}}$ & $3.7^{\mathrm{b}}$ \\
$\mathrm{T}_{5}$ & $44.73^{\mathrm{b}}$ & $156.7^{\mathrm{a}}$ & $23.17^{\mathrm{b}}$ & $25.93^{\mathrm{c}}$ & $32.33^{\mathrm{c}}$ & $11.00^{\mathrm{b}}$ & $31.0^{\mathrm{b}}$ & $5.3^{\mathrm{a}}$ \\
\hline
\end{tabular}

The quality of light has an important effect on lengthening of the stem and leaves of plants (Yağcioğlu, 2005). A wide range of light can be produced in LED light sources from ultraviolet to infrared. This presents extremely good possibilities for researchers and in recent years there has been a great increase in studies of plant production with light obtained in the visible and ultraviolet regions (Miyashita et al., 1995; Jao and Fang, 2003; Lawrance et al., 2005; Shimizu et al., 2005; Kondo et al., 2008). It has been concluded that significant changes can be made in the physiological and morphological growth and development of plants with different light combinations in particular and light quality. Brown (1995) observed that applying the combination of infrared $(735 \mathrm{~nm})$ and red $(660 \mathrm{~nm})$ light together (total $300 \mu \mathrm{mol} \mathrm{m} \mathrm{m}^{-2} \mathrm{~s}^{-1}$ ) to the pepper plant (Capsicum annum L.) resulted in a greater increase in stem biomass and plant height than red light applied alone.

\section{References}

Aceves-Avila F, Medina F, Fraga A. 2001. Therapies in rheumatology: The persistence of ancient medical practices. Clin. Exp. Rheumatol., 19: 177-83.

Anonymous. 1996. Hunter lab colour scale applications note, vol.8, No.9, Hunter associates Lab., Virginia, pp. 1-4. https://support.hunterlab.com>article_attachments [Accessed 15.09.2019].

Bach N, Thung SN, Schaffner F. 1989. Comfrey herb teainduced hepatic veno-occlusive disease. Am. J. Med., 87(1):97-99.

Blumenthal M, Busse W, Goldberg A, Gruenwald J, Hall T, Riggins C. 1998. The Complete German Commission E Monographs: Therapeutic Guide to Herbal Medicines Texas: American Botanical Council. https://annals.org/aim/article-abstract/712613/complete german-commission-e-monographs-therapeutic-guideherbal-medicines [Accessed 11.09.2019]. 
Brown C, Shuerger AC, Sager JC. 1995. Growth and photomorphogenesis of pepper plants under red lightemitting diodes with supplemental blue or far-red lighting. J. Am. Soc. Hortic. Sci., 120: 808-813.

Caglayan N, Ertekin C. 2011. Bitkisel Üretim İçin LED Yetiştirme Lambalarının Kullanımı. Uluslararası Katılımlı I. Ali Numan Kıraç Tarım Kongresi ve Fuarı. Eskişehir, Türkiye, 27-30 April 2011, ss. 1227-1232.

Caglayan N, Erteki, C. 2016. Sebze Üretiminde İlave LED Aydınlatma Uygulamaları. Tarım Makinaları Bilimi Dergisi, 12(1): 27-35.

De Albuquerque U, Monteiro J, Ramos M, de Amorim E. 2007. Medicinal and magic plants from a public market in northeastern Brazil. J. Ethnopharmacol., 110: 76-91.

Freed RD. 1988. MSTAT-C. Michigan State University. Crop and Soil Science Version 2.10.

Frost R, MacPherson H, O'Meara S. 2013. A critical scoping review of external uses of comfrey (Symphytum spp.). Complement. Ther. Med. 21: 724-745.

Furuya M. 1993. Phytochromes: their molecular species, gene families and functions. Ann. Rev. Plant Physio., 44: 617-645

Grube B, Grunwald J, Krug L, Stagier C. 2007. Efficacy of a comfrey root (Symphyti offic. radix) extract ointment in the treatment of patients with painful osteoarthritis of the knee: results of a double-blind, randomised, bicenter, placebo-controlled trial. Phytomedicine, 14: 2-10.

Hatfield G. 2005. Hatfield's Herbal: The Curious Stories of Britain's Wild Plants. London: Penguin Global. ISBN: 9780141025148.

Heckman RA. 2004. The bactericidal properties of comfrey (Symphytum officinale) herbal extracts. Department of Zoology, Brigham Young University: Pavia Sales Group, Inc. (pamphlet).

Huang J, Padmanabhan K, Collins OM. 2011. The Sampling Theorem with Constant Amplitude Variable Width Pulses. IEEE Transactions on Circuits and Systems, 58: 1178-1190.

Jao, RC, Fang W. 2003. An Adjustable Light Source for Photo-Pyhto Related Research and Young Plant Production. Appl. Eng. Agr., 19(5): 601-608.

Kondo N, Ling PP, Kurita M, Falzea PD, Nishizu T, Kuramato M, Ogawa Y, Minami Y. 2008. A Double Image Acquisition System with Visible and UV LEDs for Citrus Fruit. J. Robot. Mechatron., 21(4): 533-540.

Lawrance KC, Park B, Heitschmidt G, Windham WR. 2005. Led Lighting for Use in Multispectral and Hyperspectral Imaging. ASABE Annual International Meeting. Paper No. 053073.

Li H, Tang C, Xu Z, Liu X, Han X. 2012. Effects of different light sources on the growth of non-heading Chinese cabbage (Brassica campestris L.). J. Agr. Sci., 4: 262-273.
Matsuda R, Ohashi-Kaneko K, Fujiwara K, Goto E, Kurata K. 2004. Photosynthetic characteristics of rice leaves grown under red light with or without supplemental blue light. Plant and Cell Physiology, 45(12): 1870-1874.

McGuire RG. 1992. Reporting of objective colour measurements. HortScience, 27: 1254-1255.

Mean Well inc. 2019. LED Sürücü Teknik Dökümanları. Http://www.meanwell.com [Accessed 16.11.2019].

Miyashita, Y, Kitaya Y, Kozai T, Kimura T. 1995. Effects of Red and Far-Red Light on the Growth and Morphology of Potato Planters in vitro: Using Light Emitting Diode as A Light Source for Micropropagation. Acta Hortic., 393: 189-194.

Oberlies NH, Kim NC, Brine DR. 2004. Analysis of herbal teas made from the leaves of comfrey (Symphytum officinale): reduction of $\mathrm{N}$-oxides results in order of magnitude increases in the measurable concentration of pyrrolizidine alkaloids. Public Health Nutr., 7: 919-924.

Shimizu H, Ma Z, Tazawa S, Douzono M, Runkle E, Heins R. 2005. The application of blue light as a growth regulator. ASABE International Meeting, Paper Number: 054152.

Spalding EP, Folta KM. 2005. Illuminating topics in plant photobiology. Plant, Cell and Environment, 28(1): 39-53.

Tripathy BC, Brown CS. 1995. Root-shoot interaction in the greening of wheat seedlings grown under red light. Plant Physiology, 107: 407-411.

Ucar E, Caglayan N, Turgut K. 2016. The Effects of Various LED Light Wavelengths to the Physiological and Morphological Parameters of Stevia (Stevia rebaudiana) Bertoni. Notulae Scientia Biologicae, 8(3): 354-359.

Urbonaviciute A, Pinho P, Samuoliene G, Duchovskis P, Vitta P, Stonkus A, Tamulaitis G, Zukauskas A, Halonen L. 2007. Effect of Short-Wavelength Light on Lettuce Growth and Nutrotional Quality. Scientific Works of the Lithuanian Institute of Horticulture and Lithuanian University of Agriculture-Sodininkyst Ir Daržininkyst, 26: 157-165.

Yağcıoğlu A. 1996. Tarımsal Elektrifikasyon (Genişletilmiş 2. Basım). İzmir: EÜZF Yayınları, No:488.

Yağcioğlu A. 2005. Sera Mekanizasyonu. İzmir: Ege Üniversitesi Yayınları 562, 363 s.

Yeh N, Chung J. 2009. High-brightness LEDs Energy efficient lighting sources and their potential in indoor plant cultivation. Renewable and Sustainable Energy Reviews, (13): 2175-2180.

Zhu J, Tremblay N, Liang Y. 2012. Comparing SPAD and at LEAF values for chlorophyll assessment in crop species. Can. J. Soil. Sci., 92: 645-648 